\title{
Amotivation in Filipino ESL Learners: Exploring Some Correlates
}

Rochelle Irene G. LuCAS

De La Salle University

Allan B. I. Bernardo

University of Macau

Mildred A. Rojo-Laurilla

De La Salle University

Received: 4 December 2014 / Accepted: 10 September 2015

ISSN: $1697-7467$

\begin{abstract}
The study explores correlates of Filipino students' reasons for amotivation in learning English as a second language. Students answered questionnaires on reasons for amotivation, approaches to learning, and language use outside school. Results show that amotivation is positively associated with surface learning approaches but negatively associated with deep learning approaches. Frequency of use of English in activities outside school was also associated with dimensions of amotivation. The results indicate how amotivation arises from students' engagement of their English classes and the importance of English in their life, and can help ESL teachers identify students at risk of amotivation.
\end{abstract}

Key words: amotivation, approaches to learning, English as a Second Language, motivation.

Desmotivación en los estudiantes filipinos de inglés como segundo idioma: exploración de algunos correlatos

RESUMEN: El estudio explora correlatos de las razones por las que los estudiantes filipinos muestran "desmotivación" al aprender inglés como segundo idioma. Los estudiantes respondieron a cuestionarios sobre la desmotivación, enfoques de aprendizaje, y uso del idioma fuera del ámbito académico. Los resultados muestran que la desmotivación está positivamente asociada con enfoques de aprendizaje superficiales y negativamente con enfoques de aprendizaje profundos. También la frecuencia del uso del inglés en actividades fuera del ámbito académico se asocia con dimensiones de amotivación. Los resultados indican cómo la desmotivación proviene del compromiso de los alumnos en sus clases de inglés y la importancia del inglés en sus vidas, y pueden ayudar a los profesores de Inglés como segunda lengua a identificar a los alumnos en riesgo de desmotivación.

Palabras clave: amotivación, enfoques de aprendizaje, inglés como segunda lengua, motivación.

\section{INTRODUCTION}

As more countries consider making English a required subject or even medium of instruction in their basic and higher education curriculum (Jenkins, 2013), the issue of students' motivations in learning English becomes important. To better understand the motivations of 
English language learners, research has been undertaken to explore the structure and consequences of these motivations. But not much has been done to understand the absence of such motivations or amotivation in English language learning. In this study, we explore some possible correlates of amotivation in the Asian context, by studying a sample of Filipino students enrolled in a mandatory English language course in university.

\section{Theoretical Frame}

\subsection{Motivation and amotivation in learning English}

Much of the recent work on motivation in English language learning has adopted the motivational framework of Dörnyei (2009), which assumes that language learning motivations are tied to issues of identity. Progress has been made in studying the dimension and levels of motivations in English language learning in Asian contexts (Wong, 2014; You \& Dörnyei, 2016; Peng, 2015). In most studies of motivation to learn English in Asia, the lack of motivation is understood as a decline in the levels of motivation (Kim \& Seo, 2012). However, motivation researchers in other domains propose that the dimensions of amotivation may be different from those of motivation. A recent study of EFL teachers in Japan (Sakui \& Cowie, 2012) suggests that focusing on students' experiences of "unmotivation" may be more important as there seem to be limits to just focusing on just positive motivation.

The concept of amotivation as the absence of motivation has been explored within self-determination theories (Ryan \& Deci, 2000). The theory assumes that there is a range of motivations, and amotivation is one of the distinct dimensions in this range. In particular, amotivation is defined as a state in which individuals cannot perceive a relationship between their behavior and that behavior's subsequent outcome; instead, the outcomes are perceived to be determined by factors beyond their control. Given that the individual has no control over outcomes, the theory assumes that an amotivated person has no personal motivation to guide goal-directed behaviors. Applying this to student learning, amotivated learners are those who cannot predict the consequences of their behavior in school, and cannot see the reason for engaging school activities. They may have feelings of detachment from and invest little effort in their actions. Using this conceptualization of amotivation, some researchers have documented how academic amotivation is associated with boredom and poor concentration in class (Vallerand, Pelletier, Blais, Briere, Senecal, \& Vallieres, 1993), poor psychological adjustment and higher stress (Baker, 2003), and dropping out of school (Vallerand, Fortier, \& Guay, 1997).

In an attempt to better understand amotivation from the perspective of the learner, Legault, Green-Demers, and Pelletier (2006) suggested a classification of students' reasons for being amotivated. They proposed a taxonomy with four dimensions that relate to how students perceive the learning tasks and their own capabilities to engage the tasks; these dimensions are all consistent with the broad conceptualization of amotivation according to self-determination theory (Ryan \& Deci, 2000). These dimensions are (a) value of task how important learning tasks are in the student's life, (b) ability beliefs - the belief that one does not have the personal ability to execute and complete the required tasks, (c) task characteristics - negative perceptions or attitudes about the tasks, and (d) effort beliefs - the 
belief that they cannot maintain the effort required to complete the tasks. Recent qualitative research indicates that these dimensions overlap with Filipino learners reasons for not being motivated in school (Salanga \& Bernardo, 2016).

Although there have been previous efforts to draw from self-determination theory to understand students' motivation to learn a second or foreign language (Noels, Pelletier, Clement, \& Vallerand, 2002), this conceptualization of amotivation and its reasons have not been explicitly explored in the domain of learning English as a second or foreign language. There have been attempts to inquire into how teachers perceive students' low motivations or even resistance to learn English as a second language (Cowie \& Sakui, 2011; Sakui \& Cowie, 2012), but so far, there are no published studies that inquire into ESL or EFL students' own reasons for amotivation in learning English as a second or foreign language. In this study, we adopt the proposed taxonomy of students' reasons for amotivation to explore the phenomenon in a sample of English language learners in the Philippines.

\subsection{Correlates of amotivation}

Our study focused on factors that might influence the reasons for being amotivated in learning English as a second language. The first factor considered was students' approach to learning in their English classes. Approach to learning is an important predictor of academic achievement (Entwistle \& Ramsden, 1983; Marton \& Saljo, 1984) even with Filipino students (Watkins, Hattie, \& Astilla, 1986; Bernardo, 2003). Studies typically differentiate between deep and surface approaches to learning. Deep approach involves more conceptual learning strategies to understand the meaning of the learning material and to attaining higher levels of mastery and performance. Surface approach involves the use of rote memorization and other lower level learning strategies to meet required levels of performance. In ESL and EFL, examples of deep approaches include semantic encoding and word structure in vocabulary learning, resourcing, and translation, whereas examples of surface approaches include repetition and rote memorization for vocabulary learning and meaning-oriented note-taking strategies (Hsiao \& Oxford, 2002; Ping, Baranovich, Manueli, \& Siraj, 2015). ESL and EFL learners are likely to use a variety of strategies for different tasks in the English classes, but they are also quite likely to prefer or to use some types of strategies more often than others. The use of either surface or deep approaches to learning often reflects how students engage their class activities; with those who more frequently use deep approaches to learning being more engaged. As such, we believe that the tendency to use surface and deep approaches to learning reflect their level of engagement in their English classes, which should relate to their motivation or, in this study, to their reasons for amotivation.

We hypothesize that amotivation arises in students who adopt surface learning approaches more frequently, but less so in students who use deep learning approaches more. The tendency to adopt and to use more surface approaches could be associated with beliefs about the low value and negative characteristics of learning tasks, and/or low beliefs about one's ability to complete the task. These beliefs seem to be consistent with the conditions for amotivation as defined in self-determination theory. In contrast, students who more frequently adopt and use deep learning approaches are more likely to give importance and have positive perceptions of the learning tasks and their ability to complete such tasks. We predict that the dimensions of amotivation would be positively associated with the surface approach but negatively associated with the deep approach. 
We also propose that the students' language related activities outside the classroom could be associated with reasons for being amotivated, as the use of English in various activities outside the classroom could indicate how integral English is in their lives. Filipino learners of English as a second language speak Filipino language at home and in most of their social and academic activities. However, they would typically have opportunities to use English in various activities as English is also used in many domains of Philippine social life, especially in relation to their educational and intellectual activities as Filipino-English bilingual education is the official policy in most of formal education (Bernardo, 2004; 2007). But the actual use of English in these activities varies a lot across different learners; while some learners may be comfortable and prefer to use English in their conversations, most learners would be more comfortable using their mother tongue in most of their activities. Those learners who use English frequently in conversations with family and friends are likely to value the various learning tasks in their English class, and perhaps to feel competent in tasks that require the use of English. Learners who read books and magazines or watch television shows and movies in English are also more likely to have the same beliefs related to learning English. On the other hand, the reverse might be true for learners who use their first language, Filipino, more frequently in these activities outside school. Note however, that the use of English or Filipino is not a zero-sum proposition, and students might actually use both as frequently outside the English language classroom. So we inquired into the students' frequency of use of the two languages outside the English classroom, but we predict that it is the frequency of use of English that would be negatively associated with various reasons for being amotivated, whereas use of Filipino may not be consistently associated with amotivation.

In summary, the present study seeks to understand the correlates of the different dimensions of the reasons for amotivation in learning English as a second language among Filipino learners. We focus on two sets of factors - the learning strategies that refer to activities within the classroom learning environment, and the frequency of using English and Filipino in activities outside the classroom learning environment.

\section{Method}

\subsection{Participants}

Participants were 225 first year students (60.7\% female, ages: 16 to 18 years) enrolled in a required English course in a university in Metro Manila. All students had Filipino as their first language and have English as a second language. All students gave their informed consent to participate in the study.

\subsection{Instruments}

\subsubsection{Academic Amotivation Inventory}

The scale developed by Legault, Green-Demers and Pelletier (2006; Green-Demers, Legault, Pelletier, \& Pelletier, 2009) was used to measure reasons for amotivation in the English class the students were taking. The scale had 16 items describing reasons why 
students sometimes lack motivation in class, which were grouped into four subscales: value of task ( $\mathrm{a}=.85$; sample item: "Because I have no good reason to study"), ability beliefs (a $=.88$; "Because the tasks demanded of me surpass my abilities"), task characteristics $(\mathrm{a}=$ .80 ; "Because my school work is not stimulating), and effort beliefs $(\mathrm{a}=.83$; "Because I'm a bit lazy"). For each item, participants were supposed to answer in a scale from 1 (does not fit me or my situation) to 7 (exactly fit me or my situation).

\subsubsection{Study Process Questionnaire}

The Study Process Questionnaire (R-SPQ-2F) developed by Biggs, Kember, and Leung (2001) was used to assess the students' approaches to learning. A version of the same questionnaire was previously used and validated with similar Filipino university students (Zhang $\&$ Bernardo, 2000; Bernardo, 2003). The 20 items in the questionnaire are grouped into two scales: surface approach $(\mathrm{a}=.71$; sample item: "I only study seriously what's given out in class or in the course outlines.") and deep approach $(\mathrm{a}=.77$; "I find that at times that studying gives me a feeling of deep personal satisfaction"), and were answered using a scale from 1 (this item is never or only rarely true of me) to 5 (this item is always or almost always true of me). The participants were asked to think about the English class they were taking when answering the items. Each scale can be further divided into the motive and strategy subscales with 5 items each, but only the scale scores were analyzed in this study.

\subsubsection{Language-related activities.}

The students were also asked to indicate how often they engaged in some language related activities outside the classroom (see Table 1). The students were asked to answer using a scale from 1 (never or rarely) to 5 (always).

\section{RESULTS}

The descriptive statistics are summarized in Table 1, but the results of interest are in Table 2, which shows the relationship between the dimensions of amotivation and the other variables. As predicted, surface approach was positively correlated with all amotivation dimensions, and deep approach was negatively correlated with three of these dimensions. These relationships were further explored using multiple regression analysis, and the results summarized in Table 3 confirm the results of the correlational analysis. 
Table 1. Descriptive statistics

\begin{tabular}{|c|c|c|}
\hline & $M$ & $S D$ \\
\hline \multicolumn{3}{|l|}{ Amotivation } \\
\hline - Value of task & 1.82 & 1.04 \\
\hline - Ability beliefs & 2.05 & 1.16 \\
\hline - $\quad$ Task characteristics & 2.29 & 1.12 \\
\hline - Effort beliefs & 2.66 & 1.21 \\
\hline \multicolumn{3}{|l|}{ Approaches to learning } \\
\hline - Surface approach & 3.02 & 0.59 \\
\hline - Deep approach & 2.68 & 0.58 \\
\hline \multicolumn{3}{|l|}{ Language-related activities } \\
\hline - Use English at home when talking to family & 2.51 & 1.19 \\
\hline - Use English when talking to friends & 2.63 & 1.08 \\
\hline - Read books, magazines or newspapers in English & 3.91 & 1.07 \\
\hline - Watch TV shows and movies in English & 4.30 & 0.90 \\
\hline - Use Filipino at home when talking to family & 3.77 & 1.23 \\
\hline - Use Filipino when talking to friends & 3.88 & 1.04 \\
\hline - Read books, magazines or newspapers in Filipino & 1.93 & 0.99 \\
\hline - Watch TV shows and movies in Filipino & 2.50 & 1.07 \\
\hline
\end{tabular}

Table 2. Correlates of amotivation

\begin{tabular}{|c|c|c|c|c|}
\hline \multirow[b]{2}{*}{ Learning approach } & \multicolumn{4}{|c|}{ Correlations $(r)$} \\
\hline & Value of task & Ability beliefs & $\begin{array}{c}\text { Task } \\
\text { characteristics }\end{array}$ & Effort beliefs \\
\hline - $\quad$ Surface approach & $.36^{* *}$ & $.28 * *$ & $.39 * *$ & $.38^{* *}$ \\
\hline - Deep approach & $-.19 * *$ & -.02 & $-.18 * *$ & $-.22 * *$ \\
\hline Language-related activities & & & & \\
\hline $\begin{array}{l}\text { - Use English at home when talking to } \\
\text { family }\end{array}$ & -.07 & $-.27 * *$ & -.10 & -.11 \\
\hline - Use English when talking to friends & -.12 & $-.25 * *$ & $-.14^{*}$ & $-.14 *$ \\
\hline $\begin{array}{l}\text { - Read books, magazines or newspapers } \\
\text { in English }\end{array}$ & $-.14^{*}$ & $-.28 * *$ & -.10 & $-.18^{*}$ \\
\hline $\begin{array}{l}\text { Watch TV shows and movies in } \\
\text { English }\end{array}$ & -.08 & $-.25 * *$ & -.01 & -.03 \\
\hline $\begin{array}{l}\text { - Use Filipino at home when talking to } \\
\text { family }\end{array}$ & -.02 & .12 & .01 & .05 \\
\hline - Use Filipino when talking to friends & .02 & $.19 * *$ & .09 & $.15^{*}$ \\
\hline $\begin{array}{l}\text { - Read books, magazines or newspapers } \\
\text { in Filipino }\end{array}$ & .00 & .09 & -.04 & -.00 \\
\hline $\begin{array}{l}\text { - Watch TV shows and movies in } \\
\text { Filipino }\end{array}$ & .02 & $.14^{*}$ & .07 & .01 \\
\hline
\end{tabular}


The predictions regarding the influence of language activities outside the English classroom where only partially supported. The negative correlation between the use of English in various activities was only consistently found with ability beliefs; not all activities were correlated with the other amotivation dimensions. Interestingly, there were some positive correlations between use of Filipino outside the classroom and some of the amotivation dimensions. These results were also confirmed in the multiple regression analysis of the results shown in Table 3. Only the regression model for ability beliefs was significant, and only reading in English and talking to parents/family in English seemed to be negatively associated with ability beliefs.

Table 3. Summary of multiple regression analysis

\begin{tabular}{|c|c|c|c|c|}
\hline \multirow[b]{2}{*}{ Learning approach } & \multicolumn{4}{|c|}{ Standardized coefficients $(\beta)$} \\
\hline & Value of task & Ability beliefs & $\begin{array}{c}\text { Task } \\
\text { characteristics }\end{array}$ & Effort beliefs \\
\hline - Surface approach & $.36^{* *}$ & $.28 * *$ & $.39^{* *}$ & $.38^{* *}$ \\
\hline - Deep approach & $-.19 * *$ & -.01 & $-.17 * *$ & $-.22 * *$ \\
\hline - $R^{2}$ & .17 & .08 & .18 & .19 \\
\hline - $\quad F(2,221)$ & $21.98 * *$ & $9.52 * *$ & $24.74 * *$ & $26.00 * *$ \\
\hline \multicolumn{5}{|l|}{ Language-related activities } \\
\hline $\begin{array}{l}\text { - Use English at home when talking to } \\
\text { family }\end{array}$ & -.02 & $-.19^{+}$ & -.06 & -.05 \\
\hline - Use English when talking to friends & -.13 & -.06 & -.08 & -.05 \\
\hline $\begin{array}{l}\text { - Read books, magazines or newspapers } \\
\text { in English }\end{array}$ & -.13 & $-.17 * *$ & -.11 & $-.19 *$ \\
\hline $\begin{array}{l}\text { Watch TV shows and movies in } \\
\text { English }\end{array}$ & -.01 & -.12 & .08 & .07 \\
\hline $\begin{array}{l}\text { - Use Filipino at home when talking to } \\
\text { family }\end{array}$ & -.10 & -.13 & -.16 & -.13 \\
\hline - Use Filipino when talking to friends & -.02 & .08 & .09 & .17 \\
\hline $\begin{array}{l}\text { - Read books, magazines or newspapers } \\
\text { in Filipino }\end{array}$ & .01 & .04 & -.09 & .01 \\
\hline $\begin{array}{l}\text { Watch TV shows and movies in } \\
\text { Filipino }\end{array}$ & -.00 & .01 & .11 & -.05 \\
\hline - $\quad R^{2}$ & .04 & .15 & .05 & .06 \\
\hline - $\quad F(8,215)$ & 1.04 & $4.68^{* *}$ & 1.32 & 1.73 \\
\hline
\end{tabular}




\section{Discussion}

The study was undertaken to understand the correlates of students' reasons for amotivation in learning English as a second language in Filipino university students. We can view the results of the study as suggesting possible indicators of vulnerability to amotivation in English learners. In particular, those who use more surface approaches (and less deep approaches), and those who do not use English as often in their conversations and leisure activities outside the English classroom. Learners who use more surface approaches in their English language classes may be expressing beliefs about their low abilities related to the required tasks of the class or that these tasks are uninteresting or unimportant. The students use of English and Filipino outside the classroom relate to their own ability beliefs related to the class requirements in English; understandably, those who use English less and use Filipino more in their social and personal activities outside the English language classroom are more likely to report lower ability beliefs. Because English is predominantly used as the language in schools in the Philippines, these lower ability beliefs may be associated with students' lower motivation to engage tasks in English classes in a deeper way or their tendency to engage the task is the easiest possible way. It is also possible that the less frequent use of English in activities outside school may reflect more negative attitudes towards the English language, which is also an important reason for being amotivated in English language classes.

Note that these indicators should not be viewed as causing amotivation, as our research design does not warrant such an assertion. In so far as the learning strategies are concerned, it is actually conceivable that amotivation may actually be influencing the greater use of the surface learning strategies and the lesser use of deep strategies, or that amotivation and strategies reciprocally influence each other. This plausible relationship can be studied in future research that adopt more longitudinal research designs (see e.g., Dörnyei \& Csizer, 2002) and can provide very useful insights into how amotivation works in shaping the actual learning strategies adopted by ESL learners.

But the identification of such correlates is a small but important step towards knowing which students are at-risk for amotivation and towards developing a fuller understanding of the processes that cause amotivation in English language learners. For example, English language teachers who are attentive to how their students engage the learning activities in the classroom can observe which students are using surface level strategies and assume that they may be likely candidates for experiencing amotivation in learning English. Being attentive to students' learning strategies will require formative assessment approaches that reveal how individual students approach the learning tasks. Teachers might need to inquire more directly to how a student tackled a particular task or how they prepare for activities in their English classes. Or teachers could introduce activities that would help students monitor their own activities and performance in class.

Once the students who use surface learning strategies are identified, the students can be either helped to engage the tasks using deeper level strategies or the tasks for them can be redesigned so that they can gradually acquire deeper level strategies in engaging the tasks. A lot of studies (e.g., Wang, 2011; Fuchs, Hauck, \& Muller-Hartmann, 2012; Benson, 2013; Kaur, Hashim, \& Noman, 2015;) have found that students who learn their second language in an autonomy supportive environment where feedback enhances their sense of 
competence in the learning tasks are likely to be more motivated, to learn better, to feel less anxious, and to be less likely to give up on learning tasks. So teachers might design specific tasks for these students who tend to use surface learning strategies so they would feel more autonomous and self-regulated in their English class. Teachers could also use other alternative learning platforms for these students, which might encourage them to use deeper and less surface strategies.

Similarly, English teachers can survey how their students use English and their native language outside the classroom, and use this information as guides for identifying who are likely to have lower ability beliefs related to the requirements of the class or who have lower values for learning English. Interestingly, previous research with Filipino learners in other domains of learning indicate that teacher support actually predicts students' own value and ability beliefs related to learning (Ganotice, Bernardo, \& King, 2013), so English teachers could also play a supporting role in possibly buffering the relationship between these indicators and student amotivation. Otherwise, just knowing who are likely to have lower English ability beliefs could help the teacher know who may need more attention in sustaining their motivations in the English language classes. Although our study does not directly point to these suggestions, we can reasonably speculate that proactively targeting these factors that predict amotivation might help prevent amotivation from fully taking root in the vulnerable students.

Mindful of the fact that the meanings of English in Philippine education might be very different from how English is experienced in other countries, we recommend that future studies replicate our research design in studying English language learners from other cultural backgrounds. Doing so would help to validate whether the predictors are consistent across either sex, age group or cultural background, and possibly point to some processes that are unique or specific to the culture or educational system of particular countries that may influence amotivation of different learners.

We also recommend future studies to look at other possible predictors of amotivation, as this is an area of language learning that needs to be explored further. Aside from students' learning strategies, it might be interesting to explore the learners' learning goals, aspirations, beliefs, and identities that are typically associated with motivation and achievement in learning in English as well as in other domains of learning (Peng, 2015). Beyond these possible student-related variables, future research might also explore variables related to the teachers, the instructional processes, learning materials and activities themselves (Lasagabaster \& Beloqui, 2015), and maybe even the classroom and school environment (Barrot, 2015). Although these variables have been typically explored in relation to learner motivation, these have not actually been investigated systematically in relation to learner amotivation, much less to amotivation in English language learning.

Thus, although we believe that our study makes some contributions to understanding amotivation of English language learners, we also believe that there is much more that ESL and EFL teachers and researchers need to explore in relation to this very important aspect of learning English as a second or foreign language in order to provide teachers of ESL and EFL better insights as to how to avoid amotivation among their students. 


\section{REFERENCES}

Baker, S.R. (2003). "A prospective longitudinal investigation of social problem-solving appraisals on adjustment to university, stress, health, and academic motivation and performance", in Personality and Individual Differences, 35, 3: 569-591.

Barrot, J.S. (2015). "A sociocognitive-transformative instructional materials design model for second language (L2) pedagogy in the Asia Pacific: development and validation", in The Asia Pacific-Education Researcher, 24, 2: 283-297.

Benson, P. (2013). Teaching and Researching: Autonomy in Language Learning. New York: Routledge.

Bernardo, A.B.I. (2003). "Approaches to learning and academic achievement of Filipino students", in Journal of Genetic Psychology, 164, 1: 101-114

Bernardo, A.B.I. (2005). "Bilingual code-switching as a resource for learning and teaching: Alternative reflections on the language and education issue in the Philippines", in D.T. Dayag and J.S. Quakenbush (eds.), Linguistics and Language Education in the Philippines and Beyond. Manila, Philippines: Linguistic Society of the Philippines, 151-169.

Bernardo, A.B.I. (2007). "Language in Philippine education: Rethinking old fallacies, exploring new alternatives amidst globalization", in T.R.F. Tupas (ed.), (Re)making Society: The Politics of Language, Discourse and Identity in the Philippines. Quezon City, Philippines: University of the Philippine Press, 1-26.

Biggs, J., Kember, D. and Leung, D.Y.P. (2001). "The revised two-factor study process questionnaire: R-SPQ-2F”, in British Journal of Educational Psychology, 71, 2: 133-149.

Cowie, N. and Sakui, K. (2011). "Critical but neglected: EFL teachers' perspectives on learner motivation", in G. Murray, A. Gao, and T. Lamb (eds.). Identity, Motivation, and Autonomy: Exploring the Links. Bristol, UK: Multilingual Matters, 212-228.

Dörnyei, Z. (2009). "The L2 motivational self-system”, in Z. Dörnyei and E. Ushioda (eds.), Motivation, Language Identity and the L2 Self. Clevedon, UK: MultilingualMatters, 9-42.

Dörnyei, Z. and Csizer, K. (2002). "Some dynamics of language attitudes and motivation: Results of a longitudinal nationwide survey", in Applied Linguistics, 23, 4: 421-462.

Entwistle, N. and Ramsden, P. (1983). Understanding Student Learning. London: Croom Helm.

Fuchs, C., Hauck, M. and Müller-Hartmann, A. (2012). "Promoting learner autonomy through multiliteracy skills development in cross-institutional exchanges", in Language Learning \& Technology, 16, 3: 82-102.

Ganotice, F. A., Bernardo, A. B. I. and King, R. B. (2013). "Adapting the Facilitating Conditions Questionnaire (FCQ) for bilingual Filipino adolescents: Validating English and Filipino versions", in Child Indicators Research, 6, 2: 237-256

Green-Demers, I., Legault, L., Pelletier, D. and Pelletier, L. G. (2008). "Factorial invariance of Academic Amotivation Inventory (AAI) across gender and grade in a sample of Canadian high school students", in Educational and Psychological Measurement, 68, 5: 862-880.

Hsiao, T. Y. and Oxford, R. L. (2002). "Comparing theories of language learning strategies: A confirmatory factor analysis", in Modern Language Journal, 86, 3: 368-383.

Jenkins, J. (2013). English as a Lingua Franca in the International University: The Politics of Academic English Language Policy. New York: Routledge.

Kaur, A., Hashim, R. A. and Noman, M. (2015). "Teacher autonomy support intervention as a classroom practice in a Thai school", Journal for Multicultural Education, 9, 1: 10-27.

Kim, T.-Y. and Soo, H.-S. (2012). "Elementary school students' foreign language learning demotivation: A mixed-method study of Korean EFL context", in The Asia-Pacific Education Researcher, 21, 1: 160-171. 
Lasagabaster, D. and Beloqui, R. L. (2015). "The impact of type of approach (CLIL versus EFL) and methodology (book-based versus project work) on motivation", in Porta Linguarum, 23: 41-57.

Legault, L., Green-Demers, I. and Pelletier, L. (2006). "Why do high school students lack motivation in the classroom? Toward an understanding of academic amotivation and the role of social support", in Journal of Educational Psychology, 98, 3: 567-582.

Marton, F. and Saljo, R. (1984). "Approaches to learning", in F. Marton, D. Hounsell, and N. Entwistle (eds.), The Experience of Learning. Edinburgh: Scottish Academic Press, 36-55.

Noels, K., Pelletier, L.G., Clement, R. and Vallerand, R.J. (2000). "Why are you learning a second language? Motivational orientations and self-determination theory", in Language Learning, 50, 1: 57-85.

Peng, J. (2015). "L2 motivational self system, attitudes, and affect as predictors of L2 WTC: An imagined community perspective", in The Asia Pacific-Education Researcher, 24, 2: 433-443.

Ping, A. M., Baranovich, D. L., Manueli, M. K. and Siraj, S. (2015). "Promoting self-regulation in vocabulary learning among Chinese EFL learners: A needs analysis", in The Asia-Pacific Education Researcher, 24, 1: 137-146.

Ryan, R.M. and Deci, E.L. (2000). "Self-determination theory and the facilitation of intrinsic motivation, social development, and well-being", in American Psychologist, 55, 1: 68-78.

Sakui, K. and Cowie, N. (2012). "The dark side of motivation: Teachers' perspectives on "unmotivation", in ELT Journal, 66, 2: 205-213.

Salanga, M.G.C. and Bernardo, A.B.I. (2016). "Filipino students' reasons for not being motivated in school: Insights into their implicit beliefs about motivation and learning", in R.B. King \& A.B.I. Bernardo (eds.), Psychology of Asian Learners. Singapore: Springer, 85-98.

Vallerand, R.J., Pelletier, L.G., Blais, M.R., Briere, N.M., Senecal, C. and Vallieres, E.F. (1993). "On the assessment of intrinsic, extrinsic, and amotivation in education: Evidence on the concurrent and construct validity of the academic motivation scale", in Educational and Psychological Measurement, 53, 1: 159-172.

Vallerand, R.J., Fortier, M.S. and Guay, F. (1997). "Self-determination and persistence in real-life setting: Toward a motivational model of high school drop out", in Journal of Personality and Social Psychology, 72, 5: 1161-1176.

Wang, P. (2011). "Constructivism and learner autonomy in foreign language teaching and learning: To what extent does theory inform practice?" In Theory and Practice in Language Studies, 1, 3: 273-277.

Watkins, D., Hattie, J. and Astilla, E. (1986). "Approaches to studying by Filipino students: A longitudinal investigation", in British Journal of Educational Psychology, 56, 3: 357-372.

Wong, R. M. H. (2014). "Motivation to learn English and school grade level: The case of newly arrived Hong Kong students", in Porta Linguarum, 21: 37-50.

You, C. and Dörnyei, Z. (2014). "Language learning motivation in China: Results of a large-scale stratified survey", in Applied Linguistics,

Zhang, L.-F. and Bernardo, A.B.I. (2000). "Validity of the Learning Process Questionnaire with students of lower academic attainment", in Psychological Reports, 87, 1: 284-290. 
